\title{
LEAVING IT ALL TO THE RESOURCE MANAGEMENT ACT 1991: THE DEMISE OF THE TORT OF PRIVATE NUISANCE
}

\author{
Antoinette Besier*
}

This article examines the development of the tort of private nuisance in New Zealand, with particular reference to the impact of the Resource Management Act 1991. The challenges confronting, and remedies available to, potential nuisance plaintiffs are contrasted with those provided for under the Act. Case studies of potential nuisance situations sourced from local authority files are used to illustrate some likely approaches to nuisance situations. The author argues that recent cases such as Hawkes Bay Protein Ltd v Davidson are sending the tort of private nuisance down the path of obsolescence.

\section{INTRODUCTION}

It is often assumed that the tort of private nuisance plays a complementary role to the environmental protection statutes, stepping in to protect landowner interests when local authorities ${ }^{1}$ fail in their duty. ${ }^{2}$ I question this assumption, and reach the conclusion that the tort of private nuisance is largely redundant, if not obsolete, in the New Zealand context.

I conclude that the tort is largely redundant for two main reasons. First, the expansive application of the statutory environmental management framework in New Zealand provided by the Resource Management Act 1991 (RMA) has denied private nuisance a residual support role. Secondly, the tort's own internal developments have served to constrain its application.

* Submitted for the LLB(Hons) degree at Victoria University of Wellington (supervisor: Katrine Evans). Winner of the Robert Orr McGechan Prize in 2003.

1 "Local authority" includes regional councils and territorial authorities; see Resource Management Act 1991, s 3 .

2 Conor Gearty "The Place of Private Nuisance in a Modern Law of Torts" (1989) 48 CLJ 214, 217. 
My work experience in the environmental sector using the RMA triggered my interest in this subject. At no stage in my seven years' work experience did I ever encounter the use of the tort. In addition, there appears to be a dearth of research regarding the relationship between private nuisance, the RMA, and the role that the tort plays today. There was an opportunity, therefore, to examine the interplay between the tort of private nuisance and the RMA and to discover the position of the tort in New Zealand.

At the outset it is important to note the limitations of this article. I have focused my research on private nuisance in relation to non-physical damage, described by Lord Westbury as "sensible personal discomfort". ${ }^{3}$ It is in this category of harm that the tort of private nuisance has the greatest potential to be used in a support role to the RMA.

This article begins by addressing the substance and applicability of the tort of private nuisance. This is followed by a discussion of the RMA, New Zealand's statutory environmental management framework, with particular attention paid to the role of local authorities. The application of the concept of reverse sensitivity is critical in reducing the role of private nuisance and is discussed in some detail. Five potential nuisance cases are examined in order to determine why they were resolved without recourse to the tort. In the final section I focus on the possible demise of private nuisance and query whether this is desirable.

\section{PRIVATE NUISANCE}

\section{A The Substance and Applicability of Private Nuisance}

Leading academics such as Fleming and Newark have observed that a definition of the tort of private nuisance is not easy to find. Fleming declared that the tort defies "rational exposition"4 while Newark pronounced that the tort "comprises a mass of material which proves so intractable to definition and analysis that it immediately betrays its mongrel origins." 5

Private nuisance covers a wide range of harms but the key unifying feature of the tort resides in the general kind of harm that is caused rather than any particular class of conduct. ${ }^{6}$ There are three kinds of private nuisance: nuisance by encroachment on a neighbour's land; nuisance by direct physical injury to a neighbour's land; and nuisance by interference with a neighbour's quiet enjoyment of his or her land. ${ }^{7}$

3 St Helens Smelting v Tipping (1865) 11 HLC 642 (HL) cited in Halsey v Esso Petroleum Co Ltd [1961] 1 WLR 683, 690 (QB) Veale J.

4 John G Fleming The Law of Torts (9 ed, The Law Book Company, Sydney, 1998) 457.

5 F H Newark "The Boundaries of Nuisance" (1949) 65 LQR 480, 480.

6 Fleming, above n 4, 457.

7 Hunter v Canary Wharf Ltd [1997] AC 655, 695 (HL) Lord Berwick. 
As stated earlier, this article focuses on the latter kind of nuisance, being harm that results in personal discomfort. The main reason for this is that liability for physical harm in terms of property and personal injury is generally found outside of the tort of private nuisance. The tort of negligence is commonly used for situations involving physical harm to property and, in the case of personal injury, the accident compensation scheme is able to provide relief. ${ }^{8}$ The rule established in Rylands $v$ Fletcher $^{9}$ is also able to provide a remedy in the case of physical damage and the tort of trespass can be used in situations where there is a nuisance caused by encroachment on land. Indeed, today a "typical case of private nuisance is one concerned with interference with the enjoyment of land."10

Private nuisance, therefore, provides a sound basis for determining legal liability in situations involving non-physical harm. However, I intend to examine whether or not the tort is able to undertake this role in the face of the comprehensive statutory environmental protection framework provided by the RMA. While the RMA will not protect activities that cause physical damage to a neighbouring property, it may provide for an activity that causes significant personal discomfort to the occupier of a neighbouring property.

\section{B Elements of the Tort}

Private nuisance protects those with proprietary interests in land. ${ }^{11}$ Whether private nuisance will provide a remedy for interference with the occupier's use or enjoyment of his or her land depends on the scales of reasonableness. ${ }^{12}$ The level of annoyance and discomfort must be substantial and exceed the bounds of the normal "give and take" expected of neighbours. ${ }^{13}$ The nuisance must also be caused by an emission from outside the plaintiff's land, ${ }^{14}$ such as the generation of toxic fumes from a factory, ${ }^{15}$ noise from a military aircraft base, ${ }^{16}$ or the extraordinary glare produced by a neighbouring building. ${ }^{17}$ Recently, in Hunter v Canary Wharf Ltd, Lord Goff emphasised that the nuisance must be caused by an "emanation" such as "noise, dirt, fumes, a

8 Injury Prevention, Rehabilitation and Compensation Act 2001.

9 Rylands $v$ Fletcher (1868) LR 3 HL 330.

10 Hunter v Canary Wharf Ltd, above n 7, 692 Lord Goff.

11 People with title to land, see Hunter $v$ Canary Wharf Ltd, above $\mathrm{n} 7$.

12 Bank of New Zealand v Greenwood [1984] 1 NZLR 525, 531 (HC) Hardie Boys J.

13 Kennaway $v$ Thompson [1980] 3 All ER 329, 333 (CA) Lawton LJ.

14 Hunter v Canary Wharf Ltd, above n 7, 685 Lord Goff.

15 St Helens Smelting $v$ Tipping, above $\mathrm{n} 3$.

16 Dennis v Ministry of Defence [2003] EWHC 793; [2003] EGLR 121 (QB).

17 Bank of New Zealand v Greenwood, above n 12. 
noxious smell, vibrations, and suchlike". ${ }^{18}$ This raises a question regarding whether glare can be considered an "emanation" by a future court. ${ }^{19}$

The court will also have to consider the character of the neighbourhood and make an assessment based on the "plain and sober and simple notions" of people living in the area. ${ }^{20}$ The locality is an important consideration in determining what is a reasonable activity For instance, what is acceptable in an industrial context may be unacceptable in a residential area. ${ }^{21}$ Moreover, the court may make a distinction between different types of residential areas; what may "be a nuisance in Belgrave Square would not necessarily be so in Bermondsey."22

Liability in private nuisance is not discharged by the exercise of due care. ${ }^{23}$ The utility of the defendant's conduct, ${ }^{24}$ the fact that the plaintiff came to the nuisance, ${ }^{25}$ and the existence of, and compliance with, planning permissions ${ }^{26}$ are not defences to an action in private nuisance. Damages are generally not recoverable unless the plaintiff is able to prove that the harm caused by the defendant was reasonably foreseeable. ${ }^{27}$

The tort of private nuisance thus attempts to protect property rights and achieve a balance between competing land uses. The tort appears to have great potential to be used for environmental protection in conjunction with the RMA as noted by Gearty: ${ }^{28}$

The textbooks tell us that private nuisance is an environmental tort, and they are right. There is nothing better in the common law for getting sewage out of rivers, reducing unwanted noise and cleansing the atmosphere of acid smuts, smoke and other pollutants. Its remedies - the injunction and damages - are the strongest that the courts have to offer. They respond to the extent of the harm done, not as in negligence, to the culpability of the harmer.

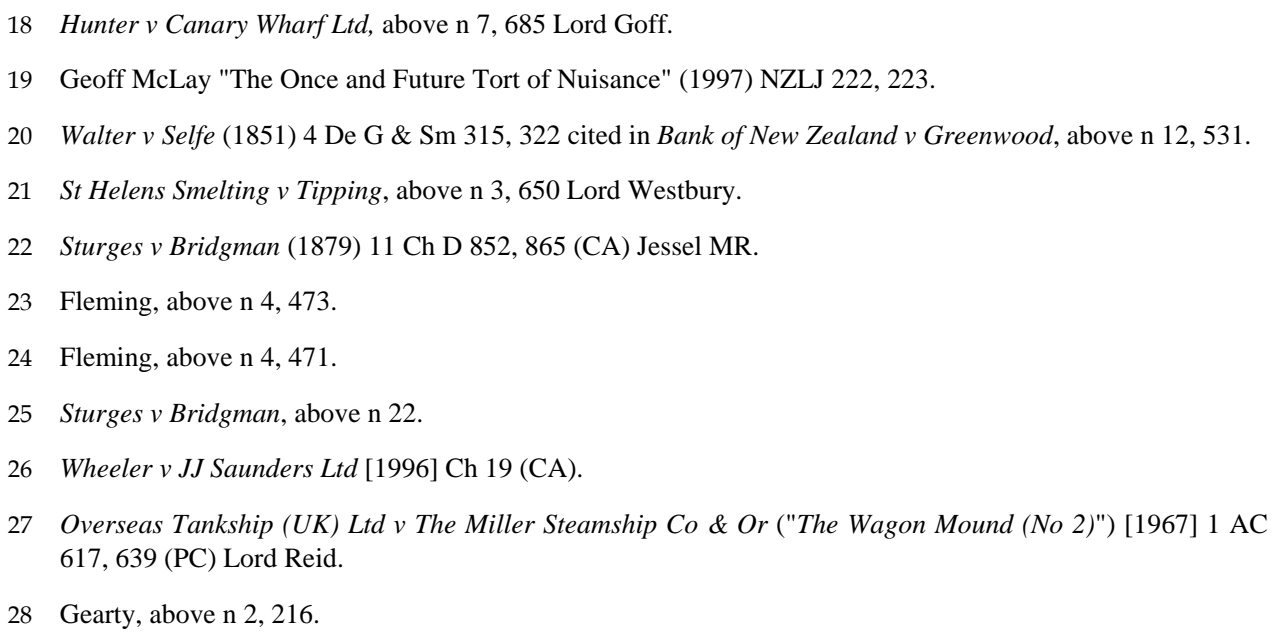


However, Gearty concludes that the tort has been "markedly underutilised" as an environmental tort and explains the tort's failure in relation to internal deficiencies. ${ }^{29}$ These include definitional problems in relation to the tort's lack of distinctness, structural issues such as costs, locus standi and the burden of proof and, lastly, the doctrinal dimension of the tort, particularly the relationship between nuisance and negligence. Gearty concludes that the tort needs to rediscover its own principles before it can turn its attention to the protection of the environment. ${ }^{30}$ While I agree that the tort is underutilised, Gearty's emphasis on change within the tort is probably not applicable to the New Zealand context. The utility of the tort depends to a large extent on the external statutory regime, as the following study on case law indicates.

\section{Case Law}

Relevant case law falls into two groups: private nuisance claims involving personal discomfort and RMA cases that affect the application of the tort.

\section{Personal discomfort cases}

There are few private nuisance cases in New Zealand that involve non-physical damage claims. In Bank of New Zealand $v$ Greenwood the tort of private nuisance proved amenable to dealing with the extraordinary glare produced by the glass verandah of a neighbouring building. ${ }^{31}$ This case occurred prior to the enactment of the RMA but it is worth noting that glare from a building is an environmental effect and that the RMA enforcement provisions could be applied to such a situation. ${ }^{32}$ However, private nuisance in this instance achieved a sound outcome and this case highlights the valuable support role that the tort is able to play when a local authority fails in their duty to protect neighbourhood amenity. Here the effect of glare was not addressed by the local authority through the planning control process which approved of the building's construction. ${ }^{33}$ Hardie Boys $\mathrm{J}$ demonstrated the inherent flexibility of the tort in providing a creative remedy to the situation: the installation of blinds on the plaintiff's building paid for by the defendant. ${ }^{34}$

The tort was also successfully applied in Matheson $v$ Northcote College where a school was found liable for the actions of its pupils who created a nuisance to the owners of a neighbouring property. ${ }^{35}$ The pupils hit golf balls and threw firecrackers and litter into the plaintiff's property.

29 Gearty, above n 2, 218.

30 Gearty, above n 2, 218.

31 Bank of New Zealand v Greenwood, above n 12.

32 See Part III A The Environmental Management Framework.

33 Bank of New Zealand v Greenwood, above n 12, 534.

34 Bank of New Zealand v Greenwood, above n 12, 536; see also Ursula Cheer "Private Nuisance Clarified" (1997) 5 Torts LJ 1, 15.

35 Matheson v Northcote College [1975] 2 NZLR 106 (SC) McMullin J. 
They also frequently trespassed on the property. These actions caused the plaintiff considerable annoyance in addition to physical damage to their property. While Matheson is possibly not a good example of the tort being applied to a personal discomfort situation, as the claim also included physical damage and trespass, the case does demonstrate the important backup role of the tort of private nuisance.

The most relevant case for the purposes of this paper is the recent case of Hawkes Bay Protein Limited $v$ Davidson involving noxious odours. ${ }^{36}$ Davidson would appear to indicate that private nuisance remains a solid option for relief where the RMA fails to resolve a nuisance situation. A closer analysis, however, reveals that this conclusion is incorrect.

The Davidsons were owners of a wool storage business in an industrial area of Napier. They brought a successful claim in private nuisance against their neighbour, Hawkes Bay Protein Limited. The latter owned a fish and meat rendering plant which generated "noxious and pungent" odours that caused the Davidsons significant discomfort. At times, the odour caused Mr Davidson to be physically ill and the Davidsons were forced to relocate their business after the Hawkes Bay Regional Council failed to control the odour problem. They experienced considerable difficulty in selling the property and eventually sold at a price that fell well short of the government valuation.

Judge Willy in the District Court held that the odour emissions from the rendering plant constituted an actionable nuisance. ${ }^{37}$ Damages were awarded for anxiety and distress $\mathbf{( \$ 3 , 0 0 0}$ to $\mathrm{Mr}$ Davidson and \$1,500 to Mrs Davidson) together with \$52,000, being the difference between the value of their property and its sale price, which was "attributable to the nuisance created and continued by the defendant."38 Judge Willy also awarded costs of $\$ 11,000$ to the plaintiffs.

The defendants appealed to the High Court regarding the finding that there was an actionable nuisance and the award of damages. Gendall $J$ upheld the finding of the District Court regarding an actionable nuisance. However, Gendall $\mathrm{J}$ allowed the appeal against the quantum of damages on the basis that when the nuisance relates to interference with the enjoyment of a property, the primary remedy for a plaintiff is an injunction, not damages. Thus general damages were reduced to $\$ 12,000$, given the plaintiffs' failure to seek an injunction.

The High Court's treatment of damages in Davidson does not augur well for the use of the tort of private nuisance in a complementary role to the RMA. Regardless of the tort's own internal developments, the RMA cases discussed below demonstrate the submergence of private nuisance within the statutory framework of the RMA.

\footnotetext{
36 Hawkes Bay Protein Limited v Davidson (28 June 2002) HC Nap AP 30/01 Gendall J.

37 Davidson, above n 36, 58 para 232.

38 Davidson, above n 36, 59 para 235.
} 


\section{Resource Management Act 1991 cases}

Cases brought under the RMA have an effect on the application of the tort. For instance, the rule established by Sturges $v$ Bridgman that the plaintiff's coming to the nuisance is no defence to an actionable nuisance, has been restricted by Auckland Regional Council v Auckland City Council. ${ }^{39}$ This case addressed the role of local authorities in the regulation of land uses. Judge Sheppard held that failure to consider "the effects [on] those who come to the nuisance, would be to fail to perform the functions prescribed for territorial authorities." 40 Auckland Regional Council assists local authorities in placing restrictions on new land uses in order to ensure that a nuisance situation does not arise.

Baragwanath $\mathrm{J}$ in the High Court supported Judge Sheppard's regulatory approach in Ports of Auckland $v$ Auckland City Council. ${ }^{41}$ This case comprised a judicial review action regarding the decision of the Auckland City Council to grant resource consent for a residential development in the immediate vicinity of the port. The port company argued that the neighbouring residents would be subjected to unreasonable noise generated by its port activities and would be likely to seek injunctive relief in a private nuisance action. It was also argued that the Council should have consulted with the company as an "affected party" and applied noise insulation conditions to the resource consent in order to protect the residents from the noise generated by the port. ${ }^{42}$ The port company was successful and the Court directed that the Council redraft the conditions of the resource consent.

The Ports of Auckland decision endorsed British authority regarding the relationship between planning permission and private nuisance. ${ }^{43}$ Baragwanath $\mathrm{J}$ approved of the judgments of Pill and Gibson LJJ in Hunter ${ }^{44}$ and Wheeler $v$ JJ Saunders Ltd ${ }^{45}$ respectively. These judgments held that planning permission does not have the same effect as statutory authority. ${ }^{46}$ The defence of statutory authority may apply when a nuisance is the result of a project that has been authorised by Parliament. Any harm that is the inevitable result of that construction does not give rise to an actionable nuisance, provided that the undertaker has carried out the works with all reasonable

39 Auckland Regional Council v Auckland City Council [1997] NZRMA 205 (EC) Judge Sheppard.

40 Auckland Regional Council v Auckland City Council, above n 39, para 108.

41 Ports of Auckland v Auckland City Council [1999] 1 NZLR 600, 612 (HC) Baragwanath J.

42 Resource Management Act 1991, s 94(1)(c)(ii), s 105(1)(a).

43 Planning permission is the same as resource consent approval under the Resource Management Act 1991.

Hunter $v$ Canary Wharf, above n 7, 695.

45 Wheeler v JJ Saunders Ltd, above n 26.

46 Ports of Auckland v Auckland City Council, above n 41, 611. 
regard and care for the interests of others. This is referred to as the Allen Principle ${ }^{47}$ and Lord Cooke applied it to the Canary Wharf development in Hunter. ${ }^{48}$ However, planning permission does not have the same effect as statutory authority, and a local authority cannot authorise a nuisance. ${ }^{49}$ It is clear, therefore, that a resource consent will not provide a defence to a claim in nuisance. Baragwanath $\mathrm{J}$ also held that compliance with a district plan rule does not afford any defence in a nuisance action. ${ }^{50}$

Baragwanath $\mathrm{J}$ argued that private nuisance should be merged within the statutory framework. Local authority decision-makers should refer to the common law in addition to the RMA at the time each statutory decision is made. ${ }^{51}$ Thus, the main conclusion that can be drawn from Ports of Auckland is that responsibility rests on local authorities to ensure that a nuisance situation does not arise in the first place. ${ }^{52}$

The direction to local authorities by the High Court in Ports of Auckland has overruled the approach taken earlier in the same year by the Environment Court in Auckland City Council v Auckland Regional Council. ${ }^{53}$ In the latter case, the Environment Court held that a local authority is not required to consider whether a decision might also be actionable in tort. ${ }^{54}$ This decision related to the City Council's appeal regarding the Regional Council's refusal to grant consent to a number of applications for the Britomart transport development. The Court rejected the argument made by supporters of the Regional Council's decision that the Council was entitled to refuse consent, as this would give rise to an actionable nuisance. ${ }^{55}$

Several points can be drawn from the cases outlined above. A local authority cannot authorise a nuisance. In addition, compliance with resource consent conditions or district or regional plan provisions cannot be used as a defence in a private nuisance action. However, the most notable feature demonstrated by the review of case law is that local authorities are responsible for ensuring that a nuisance situation does not arise by protecting existing land use activities from competing land uses. In Ports of Auckland the High Court has demonstrated a willingness to hold local

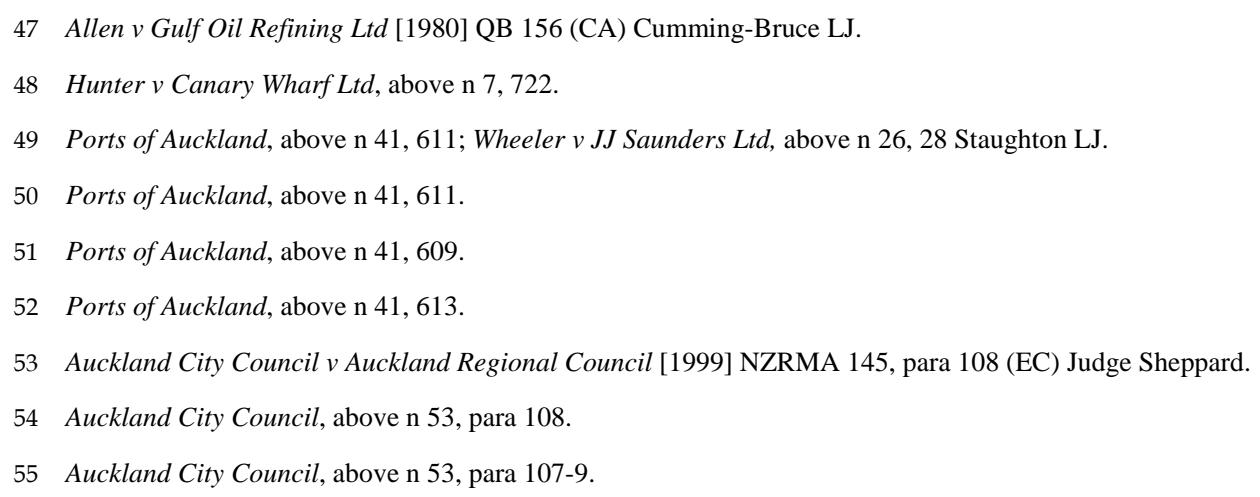


authorities to account for failing to ensure that existing land uses are protected from potential nuisance actions. The following section expands on these points by assessing the impact of the statutory environmental protection framework on the tort of private nuisance.

\section{THE RESOURCE MANAGEMENT ACT 1991}

The marginal note to section 23 of the RMA states that "other legal requirements are not affected" by the RMA. In doing so, this section has preserved common law actions. ${ }^{56}$ In the following section I will outline how, despite section 23 of the RMA, the application of the Act has left very little room for private nuisance to operate in a support role.

\section{A The Environmental Management Framework}

The RMA is a comprehensive environmental management statute. It replaced 25 natural resource and planning statutes and modified and repealed 150 laws and regulations with a "single, seamless and ambitious piece of law."57 The purpose of the RMA is the "sustainable management of natural and physical resources". ${ }^{58}$ The RMA requires sustainable management to be carried out in a way which avoids, remedies or mitigates "any adverse effects of activities on the environment". ${ }^{59}$ "Environment" is defined broadly by section 2 of the RMA to include people, communities, and social and economic conditions as well as ecosystems and amenity and cultural values.

The definition of environment is so wide that it allows RMA decision-makers to consider the full gamut of economic and social consequences of activities. ${ }^{60}$ As a result, the RMA has enabled local authorities to apply planning controls to a wide range of activities. ${ }^{61}$ This has resulted in a high level of regulation being applied to the use of land and other natural resources. ${ }^{62}$

56 David Williams (ed) Environmental and Resource Management Law (2 ed, Butterworths, Wellington, 1997) 390

57 David Young Values as Law: the History and Efficacy of the RMA (Institute of Policy Studies, Wellington, 2001) 1.

58 Resource Management Act 1991, s 5(1).

59 Resource Management Act 1991, s 5(2)(c).

60 Simon Upton, Helen Atkins and Gerard Willis "Section 5 Re-visited: A Critique of Skelton and Memon's Analysis" (2002) 3(10) Resource Management Journal 10, 14.

61 Planning controls are promulgated under local authorities and apply through district and regional plans: Resource Management Act 1991 ss 30-31.

62 Upton, above n 60, 20. 


\section{B Planning Controls}

Compliance with planning regulations is the first significant step in the prevention of actionable nuisances. Regulations generally control the location of land use activities and also set standards regarding building height, noise emission levels, discharge of contaminants and the like. ${ }^{63}$

The second step in preventing a nuisance comes through the resource consent process. Local authority decision-makers decide whether an activity that does not comply with the plan can be granted resource consent in order to be established. ${ }^{64}$ An assessment of the proposed activity's "actual and potential effects on the environment" is made in accordance with section 104 of the RMA. Given the broad definition of environment in the RMA, the assessment can include a wide range of effects including the effects of the proposed activity on the neighbourhood. ${ }^{65}$

While it is clear that the application of planning controls will mean that the occurrence of a private nuisance situation will be relatively rare, what is of concern is whether tort can be used in a situation where the local authority has failed to provide adequate protection. The following discussion addresses this point.

\section{Substitutes for Private Nuisance Remedies}

The RMA does not define "nuisance" or address civil law remedies. However, the Act provides for a range of enforcement procedures that can be utilised to end a nuisance situation. These include abatement notices, enforcement orders and directions regarding excessive noise. ${ }^{66}$ These actions provide a remedy similar to an injunction and can require people to stop undertaking an activity. Abatement notices and enforcement orders are issued to ensure compliance with the RMA or plan regulations. These can be applied to a wide range of situations where activities generate unacceptable effects.

Abatement notices are issued by local authority enforcement officers and cannot be applied for by members of the public. ${ }^{67}$ From the perspective of a potential plaintiff, an abatement notice issued by an enforcement officer of the local authority represents an expedient option to solve a nuisance problem. Neither cost nor risk of legal liability is incurred on his or her behalf and the notice can order a potential defendant to stop a nuisance or refrain from starting one.

63 See generally the Wellington City District Plan and Hamilton City Proposed District Plan.

64 Resource Management Act 1991, ss 104B-104D.

65 See generally Mobil Oil New Zealand Limited v Taupo District Council (16 December 1998) EC Taupo A149/98, para 54 Judge Whiting.

66 Resource Management Act 1991, ss 314-326.

67 Resource Management Act 1991, ss 322-325. 
Unlike an abatement notice, an enforcement order can be initiated by any person and is issued by the Environment Court. ${ }^{68}$ The RMA has provided the public with a direct right to seek enforcement orders. ${ }^{69}$ As this option will take time to go before a hearing at the Environment Court, the RMA has also provided for interim enforcement orders to be issued by the Court without a hearing when there is an immediate risk or danger to the environment. ${ }^{70}$ This option will often require the applicant to give an undertaking as to damages. ${ }^{71}$ An enforcement order can also order the reimbursement of costs that a potential plaintiff has incurred in avoiding, remedying or mitigating any adverse environmental effect. ${ }^{72}$

Other legal remedies that are available include a declaration clarifying a point of law and judicial review. The latter has proved a useful remedy in Ports of Auckland to protect the port company from any future nuisance liability by requiring the local authority to reset conditions of a resource consent to provide adequate noise insulation. ${ }^{73}$

While the RMA is able to provide relief to a potential plaintiff from a nuisance situation, it is also important to explore how the RMA has undermined the application of the tort through its expansive application. The following section addresses this matter.

\section{The Resource Management Act Takeover}

\section{Reverse sensitivity}

Reverse sensitivity is defined as the legal vulnerability of an established activity to complaint from the owners of a new land use. ${ }^{74}$ It "exists where an established use produces adverse effects and a new use is proposed for nearby land". ${ }^{75}$ The use of this concept in RMA decision-making can restrict how a property owner adjacent to an established land use activity may use his or her land.

Reverse sensitivity can provide for a potential nuisance activity to continue. An example would be allowing a quarry operator to continue operations unimpeded by controls that would protect neighbouring properties. ${ }^{76}$ Viewed from another perspective, reverse sensitivity can prevent a

68 Resource Management Act 1991, ss 314-321.

69 Williams, above n 56, 578.

70 Resource Management Act 1991, s 320.

71 Resource Management Act 1991, s 320(3)(b).

72 Resource Management Act 1991, s 314(1)(d).

73 Ports of Auckland v Auckland City Council, above n 41.

74 Bruce Pardy and Janine Kerr "Reverse Sensitivity - the Common Law Giveth and the RMA Taketh Away" (1999) 3 NZJEL 93, 93.

75 Pardy and Kerr, above n 74, 93.

76 Rowell v Tasman District Council (12 February 1997) HC Nel CP16/95 Neazor J. 
plaintiff from coming to the nuisance by restricting the use of the neighbouring land. An example of this is a local authority's refusal to allow rural residential land subdivision to proceed on land adjacent to a pig farm. ${ }^{77}$

The term "reverse sensitivity" does not appear in the RMA. Rather the concept has been developed and applied in a succession of cases by the Environment Court. ${ }^{78}$ The use of the concept involves a high degree of regulation regarding the location of land use activities. While such regulation reflects the approach used under the Town and Country Planning Act 1977, Parliament rejected this approach in the enactment of the RMA. ${ }^{79}$

Pardy and Kerr claim that the use of the concept of reverse sensitivity has had "significant consequences" for private nuisance. ${ }^{80}$ The rule established by Sturges $v$ Bridgman, ${ }^{81}$ that coming to the nuisance is no defence, has been rendered meaningless through the imposition of restrictions on adjacent land. ${ }^{82}$ Pardy and Kerr argue that the use of the concept has allowed for adverse environmental impacts to continue and be protected from legitimate legal complaint. ${ }^{83}$

Furthermore, use of the reverse sensitivity concept has introduced public interest as a consideration when assessing conflicting land uses. ${ }^{84}$ In private nuisance, an assessment of the public interest has generally been disapproved. ${ }^{85}$ Its use in resource management will mean that land uses providing economic or social benefits to the community will generally prevail. This was demonstrated in Winstone Aggregates Ltd $v$ Papakura District Council, a case regarding a submission on the content of the proposed district plan. ${ }^{86}$ The quarry provided employment and an important source of aggregate for roads in the area. The Environment Court recognised these social and economic benefits and accepted the company's submission that the quarry should be protected from future complaint. This was achieved by the imposition of a "buffer overlay" over neighbouring land which restricted the use of this land to activities that would not conflict with the quarry.

CJ McMillan Ltd v Waimakariri District Council (11 August 1998) EC ChCh C87/98 Judge Jackson.

Pardy and Kerr, above n 74, 94.

79 Ged 145.

80 Pardy and Kerr, above n 74, 96.

81 Sturges $v$ Bridgman above n 22, 865.

82 Pardy and Kerr, above n 74, 98.

83 Pardy and Kerr, above n 74, 101.

84 Pardy and Kerr, above n 74, 103.

85 Bank of New Zealand $v$ Greenwood, above n 12, 535.

86 Winstone Aggregates Ltd v Papakura District Council (14 August 1998) EC Ak, A96/98 Judge Whiting. 
The High Court has supported the position of the Environment Court and has held that if the effects of some activities cannot be reasonably internalised through restrictions and controls then "restrictions on other sites might be appropriate". ${ }^{87}$ Using this reasoning, Baragwanath J concluded that the port company could not be expected to reduce its noise emissions in order to reduce its effect on neighbouring residents.

It is clear that there are certain activities such as airports and seaports that are required by the community which cannot internalise all of their adverse effects. However, Pardy and Kerr argue that if a claim in private nuisance exists then there is no reason to justify protection of an activity under the RMA. Similarly, if no claim in private nuisance exists, then there is no need to provide protection using the concept of reverse sensitivity whereby unnecessary restrictions are placed on landowner rights. ${ }^{88}$

Pardy and Kerr's argument may fail to take into account the commercial realities of business desire (and possible need) to minimise the risk of liability. But it does raise an important issue regarding how far the public interest argument can be used to protect a potential defendant. In cases where the local authority has determined that it is in the public interest for an activity to continue, the restrictions placed on the adjacent land must be endured without compensation. ${ }^{89}$ Moreover, this means that the local authority, rather than an independent court, decides which landowner rights would prevail over the other.

Use of the concept of reverse sensitivity has also placed greater responsibility on the local authority to ensure that an existing land use is protected from legal liability arising from the environmental effects it generates. ${ }^{90}$ If the local authority fails in this task, they will be held to account through judicial review. The potential defendant has the easy ride while the burden has been shifted to the local authority. It is difficult to understand why a potential nuisance should be afforded such a high level of protection and why such an encroachment on private property rights should be accepted.

\section{E Agreements to Allow for a Nuisance}

Private agreements, whether they are covenants entered on titles or less formal arrangements, have the effect of permitting a nuisance situation to continue. These agreements are brought about when there is a change in land use.

\footnotetext{
87 Ports of Auckland v Auckland City Council, above n 41, 612. 
There are two different ways in which agreements to 'allow' a nuisance occur. The first method is through the resource consent process whereby a condition precluding complaints from the applicant (and future titleholders) is imposed as a condition of granting resource consent under section 105(1)(a) of the RMA. This arrangement would apply in a situation of reverse sensitivity, such as when an applicant was seeking to introduce a land use activity such as an airport ${ }^{91}$ or a quarry $^{92}$ that would be sensitive to an existing use. The imposition of such a condition is likely to arise as the result of negotiation between the parties ${ }^{93}$ or through a District Plan requirement. ${ }^{94}$ The arrangement is protected against changes in ownership by binding future landowners and is recorded on the certificate of title.

The second method is through a private agreement independent of the statutory processes. For example, a forestry company operating in the Tasman District regularly enters into agreements with landowners adversely affected by logging operations. Such a private agreement ends the landowner's right to object to the activity either as a submitter in the resource consent process or in a private nuisance action. ${ }^{95}$ These private agreements are not provided for in the RMA. However, the RMA has facilitated their use through its consultation provisions and emphasis on negotiated outcomes. $^{96}$

The High Court expressly approved in principle the use of such agreements in Building Industry Authority $v$ Christchurch International Airport in order to deal with the competing land use interests of the airport and property owners wishing to construct dwellings on their rural holdings close to the airport. ${ }^{97}$ This decision has been carried through into the Christchurch Proposed City Plan. Landowners who wish to construct dwellings must enter into a covenant registered against the title that the use of the building "shall endure only for so long as no complaint in relation to the noise of aircraft using Christchurch International Airport ... is made."98

A year later, the High Court in Rowell $v$ Tasman District Council relied on Christchurch International Airport to approve of the use of a covenant whereby a landowner agreed to a nuisance

91 Christchurch International Airport v Christchurch City Council [1997] NZRMA 145 (HC) Tipping J.

92 Rowell, above n 76.

93 Rowell, above $\mathrm{n} 76$.

94 City of Christchurch Proposed City Plan, 1995, Rule 2.5.7 Aircraft Noise Exposure, 4/16.

95 Telephone interview with Jack Andrews, Co-ordinator Resource Consents, Tasman District Council (the author, 13 June 2003).

Resource Management Act 1991, ss 93-95.

97 Christchurch International Airport v Christchurch City Council, above n 91, 161.

98 City of Christchurch Proposed City Plan, 1995, Rule 2.5.7 Aircraft Noise Exposure, 4/16. 
arising from a quarry in order to obtain consent for a rural residential subdivision. ${ }^{99}$ The Environment Court has also recently approved the use of a resource consent condition that prevented any future owners from initiating court proceedings in relation to the horticultural activities of a neighbour. ${ }^{100}$

The use of a condition precluding complaint in resource consents appears to be limited as revealed by my telephone survey of senior planning officers of metropolitan local authorities. ${ }^{101}$ Officers reported limited use and a general lack of awareness of such arrangements. An officer from the Tasman District Council stated that no conditions precluding complaints have been used since Rowell and that if any such agreements were reached it was through the initiative of the parties outside of the consent process. ${ }^{102}$

It is difficult to ascertain how widespread the use of private agreements is without a comprehensive survey of lawyers practising in property and resource management law. However, council officers stated that they thought that it was likely to have occurred in some instances but that their use was not widespread.

It does not appear that agreements to allow a nuisance play a significant role in diminishing the role of private nuisance. While such agreements restrict a property owner's access to courts to complain of a nuisance, property owners have been willing to pay this cost in order to live in a certain area, as indicated in Christchurch International Airport ${ }^{103}$ and Rowell. ${ }^{104}$

\section{F The Responsibility of Local Authorities}

As discussed earlier, the decision of the High Court in Ports of Auckland has ensured that it is the responsibility of a local authority to ensure that a nuisance does not happen in the first place. ${ }^{105}$

The recently announced district plan change by the Wellington City Council (WCC) to apply new noise standards for noise sensitive activities in the inner city area is a good example of a local authority ensuring that no nuisance arises. ${ }^{106}$ These standards will ensure that the conversion of

99 Rowell, above n 76.

100 JR's Orchard Limited v South Wairarapa District Council (16 June 2002) EC Wn RMA 1043/00 Judge Kenderdine.

101 See Section VIII D 2 Personal Communications.

102 Andrews, above n 95.

103 Christchurch International Airport v Christchurch City Council, above n 91.

104 Rowell, above n 76 .

105 Ports of Auckland v Auckland City Council, above n 41.

106 Wellington City Council, Proposed District Plan Change 16 - Central Area Noise Rules, May 2003. 
existing buildings for "noise sensitive activities" will require insulation, thereby avoiding a situation as occurred in 22 Ghuznee Street (addressed below).

Thus the local authority has the unenviable task of ensuring that no nuisance arises. In summary, it appears that the tort of private nuisance is unable to play any kind of support role to the RMA. The following case studies demonstrate this point clearly.

\section{CASE STUDIES REGARDING POTENTIAL NUISANCE SITUATIONS}

\section{A Selection of Cases Studied}

In order to assess the extent to which the RMA has eclipsed private nuisance, it is useful to examine how potential nuisance claims have been resolved without recourse to the tort. In consultation with officers from the Greater Wellington Council (GWC) and the WCC, five case studies were selected which represented potential nuisance claims. ${ }^{107}$ It is important to note at the outset that it was difficult to find appropriate case studies. Perhaps this is an indication in itself of how planning controls have prevented nuisance situations from arising.

All of the case studies involve personal discomfort nuisance issues related to noise and odour. The five case studies are set out in Table 1.

TABLE 1: PRIVATE NUISANCE CASE STUDIES

\begin{tabular}{|l|l|l|}
\hline \multicolumn{1}{|c|}{ Potential Defendant } & \multicolumn{1}{|c|}{ Emanation } & \multicolumn{1}{c|}{ Potential Plaintiff } \\
\hline $\begin{array}{l}11 \text { Darwin Street } \\
\text { (residence) }\end{array}$ & Smoke (chip burner) & $\begin{array}{l}\text { Owner of neighbouring } \\
\text { residence }\end{array}$ \\
\hline $\begin{array}{l}\text { 60 Kingsford Street } \\
\text { (factory) }\end{array}$ & Noise (extractor fan) & $\begin{array}{l}\text { Owners/lessees of } \\
\text { neighbouring residences }\end{array}$ \\
\hline $\begin{array}{l}22 \text { Ghuznee Street } \\
\text { bar/restaurant) }\end{array}$ & Noise (live music) & $\begin{array}{l}\text { Owners of residential } \\
\text { apartments above (same } \\
\text { building) but separate titles }\end{array}$ \\
\hline $\begin{array}{l}290 \text { Cuba Street (fast food } \\
\text { outlet) }\end{array}$ & Odour (cooking food) & $\begin{array}{l}\text { Owners of adjacent } \\
\text { residential apartment building }\end{array}$ \\
\hline 48 Kemp Street (factory) & Odour (industrial) & Owner of adjacent residence \\
\hline
\end{tabular}

107 Interview with Alison Box, Enforcement Officer WCC (the author, Wellington, 8 April 2003); Interview with Chris Keenan, Pollution Officer, Greater Wellington Council (the author, Wellington, 3 June 2003). 


\section{B Description of the Case Studies}

The potential nuisance situation at 11 Darwin Street related to the emission of smoke from a residential chip heater. A neighbouring property owner complained of thick black smoke with a noxious smell. The smoke was claimed to have an adverse effect on their children's health and it affected the use and enjoyment of their property. WCC's file on the property indicates that the period of complaint lasted from November 2002 to February 2003, at which time the Mayor informed the complainants that the WCC would not undertake any action in relation to their complaints. The GWC is responsible for the regulation of air discharges but they have no record of a complaint being lodged at this address.

The situation at 60 Kingsford Street had a more satisfactory conclusion for the potential plaintiffs. The residents of the suburban adjoining area complained about the noise emissions from a new joinery factory located at the address. The WCC officers undertook noise measurements and initiated enforcement proceedings under the RMA as the level of noise exceeded District Plan standards. Within a short period of time the factory owners had undertaken measures to reduce noise emissions and no further complaints were received.

Another noise emission case study, 22 Ghuznee Street, presented a more complex situation for the WCC. In May 2000 a café moved into the ground floor of a residential apartment block. The café played live music in the evening three to four times a week and generated a large number of complaints from the residents above. ${ }^{108}$ After several attempts to reduce noise emission levels, the WCC issued an abatement notice. The owner of the café appealed the notice to the Environment Court. In the interim, music continued to be played. Six months later, the Environment Court upheld the abatement notice, but by this stage the café owner had decided to sell his business.

At 290 Cuba Street, the odour emissions from a fast food outlet caused some distress to the residents of a new apartment block on an adjacent street. The owner of the fast food business was resistant to making any changes that would reduce odour emissions and was critical of the complainants and their motivation for making the complaints. Eventually he engaged a lawyer and worked alongside the GWC to implement changes to reduce the emission of odour.

The GWC took a different approach to the potential odour nuisance problem generated by a wool testing factory located at 48 Kemp Street. After receiving a couple of complaints from a neighbouring resident, the GWC investigated the factory and initiated enforcement action which required that the factory owners comply within a short period to reduce the "offensive and objectionable" odour and pay a fine of $\$ 1000$. The factory owners introduced some odour mitigation measures and no further complaints were received.

10822 Ghuznee Street (WCC reference: 71510). 


\section{Existence of Potential Nuisance Claims}

Each case supported a claim in private nuisance to a greater or lesser extent. For the purposes of this article, it is assumed that the potential plaintiff is an owner or tenant of the property and therefore satisfies the locus standi requirement of the tort.

In all of the case studies there is an emanation in the form of odour or noise arising from the potential defendant's land and affecting the potential plaintiff's land. A strong case could be made that, in three of the case studies (48 Kemp Street, 290 Cuba Street and 60 Kingsford Street), the emanation amounted to a substantial and unreasonable interference with the potential plaintiff's enjoyment of his or her property. In relation to $48 \mathrm{Kemp}$ Street and 290 Cuba Street, the odour emissions were noticeable to the residents of the neighbouring area during business hours (and evenings and weekends for 290 Cuba Street), thus being frequent and of long duration. From the accounts given on the files, it appears that the odour had a strong effect and made the surrounding area an unpleasant place to occupy.

Similarly, the noise emissions at 60 Kingsford Street were during business hours and were of high intensity. However, issues arise regarding whether 22 Ghuznee Street and 11 Darwin Street can satisfy the requirement of substantial and unreasonable interference. While the WCC issued excessive noise directions and an abatement notice to the bar owners regarding the noise from the café, it could be argued that live music played at an entertainment venue in the evenings in an inner city location cannot be considered unreasonable given the context of the neighbourhood. An element of "give and take" may be expected in an area that serves as an entertainment district. Nevertheless, there remains a strong case for the apartment owners given the high level of interference the music had on the enjoyment of their property, particularly disruption to their sleep patterns. Five apartments were temporarily vacated by their owners due to the level of noise interference. $^{109}$

At 11 Darwin Street it is unclear that the level of interference was unreasonable given the limited duration of the pungent smoke emission. Council officers' investigations concluded that the smoke was a problem for a very short time. The Mayor stated in a letter to the complainant "other than smoke from the initial start-up period [of the chip burner], I am satisfied with the officer's assessment that a smoke nuisance does not exist". 110

In all cases, the potential nuisance was continued by the potential defendants after they were made aware of the interference caused to the potential plaintiff. Similarly, the harm incurred by the potential plaintiffs was reasonably foreseeable. Having established that the case studies represent potential nuisance claims, I now turn to discuss the main findings of the case study research.

10922 Ghuznee Street, above.

11011 Darwin Street (WCC: 171504). 


\section{Main Findings}

\section{Awareness of nuisance claim option}

The information contained on the property files has revealed a limited awareness by potential plaintiffs of the tort of nuisance as an option available to resolve the nuisance situation. The potential plaintiff regarding 11 Darwin Street obliquely referred to other courses of action available, but did not specify what they may be. ${ }^{111}$ The potential plaintiffs of 22 Ghuznee Street were clearly determined to resolve the matter and applied pressure on the WCC to address the situation but stopped short of threatening private legal action against the emission of noise from the cafe below. ${ }^{112}$

Private nuisance is only mentioned once in the files. The reference was made in correspondence from a lawyer engaged by the WCC to advise on the matter of 11 Darwin Street. It simply advised that the tort was an option available for the complainant to pursue independently of the WCC. ${ }^{113}$

It must be noted that research has been limited to the files held by the WCC and GWC and that this may not necessarily provide a complete record of the situation.

\section{Reliance on local authorities}

It is also evident that the potential plaintiffs placed great reliance on the WCC and GWC to resolve the potential nuisance situation. At no stage did any of the potential plaintiffs prefer to act independently. In each case study, the potential plaintiff made a complaint to the WCC or GWC and waited until the matter was resolved. Often it took more than one complaint, as in the case of 22 Ghuznee Street where the potential plaintiffs lodged 66 complaints over a period of less than two months. ${ }^{114}$ The owners of the apartment building adjacent to the fast food outlet in Cuba Street complained on at least ten occasions. ${ }^{115}$

Reliance by potential plaintiffs on local authorities to resolve nuisance situations is not unexpected, given the low risks and costs presented by this option. However, as I explain later, private nuisance is constrained from providing even a backup role when a potential plaintiff is unable to rely on a local authority. So even if any of the potential plaintiffs had wanted to pursue a private nuisance claim, the tort may prove to be an unattractive option.

11111 Darwin Street, above n 110.

11222 Ghuznee Street, above n 108.

11311 Darwin Street, above n 110.

11422 Ghuznee Street, above n 108.

115290 Cuba Street (GWC file: Chicky's Charcoal Chicken). 


\section{Effectiveness of the Resource Management Act in addressing the nuisance situation}

In all the case studies except 11 Darwin Street, the potential nuisance situations were resolved without recourse to a private nuisance claim. The case studies demonstrate that the RMA enforcement mechanisms and remedies are capable of effectively ending a nuisance problem.

A potential nuisance situation involving noise emissions can be quickly resolved without recourse to the tort of private nuisance because of the availability of objective noise assessment methods. This is best demonstrated in the case study of 60 Kingsford Street.

At 60 Kingsford Street, the complaints lodged by the potential plaintiffs were supported by an officer's noise assessment. The officer measured the noise emissions from the factory at the property boundary and using the noise standards of the District Plan, judged them to be "unreasonable". ${ }^{116}$ An abatement notice was issued against the potential defendant requiring action to reduce noise emissions to within the prescribed standards. After a short period, the potential nuisance situation was resolved through changes in the design of the factory. No further complaints regarding the factory have been received since. ${ }^{117}$

Odour emissions present a greater problem. There are no objective criteria to assess the level of unreasonableness of odour emissions. This can lead to a potential defendant claiming that the complaint is unduly sensitive, as in the case of 290 Cuba Street. ${ }^{118}$ Despite this, the nuisance situation at $48 \mathrm{Kemp}$ Street was resolved within a short period of time (approximately six weeks).

In the cases of 60 Kingsford Street and 48 Kemp Street, the process of achieving an end to the nuisance was very straightforward and was achieved over a short period of time. It took a longer period for 290 Cuba Street and 22 Ghuznee Street, four and six months respectively, but this period is most likely to be shorter than the time it would take to have a civil case heard. Civil remedies are generally recognised as being very costly and slow to obtain redress. ${ }^{119}$ Thus, despite the delays evidenced by two case studies, the RMA is likely to prove more attractive in terms of the time it takes to relieve the potential plaintiffs from the nuisance problem.

For a situation such as 22 Ghuznee Street, where there are weaknesses in establishing the potential plaintiff's case, the RMA is an expedient option in addressing a nuisance problem. However, the RMA cannot provide damages for a potential plaintiff who has suffered material

11660 Kingsford Street (WCC: 304444).

117 Since the file was last reviewed 13 June 2003.

118290 Cuba Street, above n 115.

119 D J Berwick Resource Management Law Reform Group: Enforcement and Compliance Issues in Resource Management. Working Paper No 30 (Ministry of the Environment, Wellington, 1988) 50. 
interference to the enjoyment of his or her property. This is likely to be the main reason why a civil action will be pursued, as demonstrated in the case of Davidson below.

\section{THE PATH TOWARDS OBSOLESCENCE}

\section{A The Recent Decision of Hawkes Bay Protein Limited v Davidson}

The case of Davidson was discussed in the review of case law but is worthy of further analysis. Instead of pointing towards a support role for private nuisance in protecting landowners from personal discomfort, Davidson highlights the limitations of the tort. These limitations combined with the expansive application of the RMA have had the effect of rendering private nuisance largely obsolete.

The lawyer for the plaintiff in Davidson stated that the main reason why a nuisance action was undertaken was the remedies afforded by the common law, "namely recovery of a variety of categories of damages ... made the process more attractive". ${ }^{120}$ The plaintiff had been forced to relocate their business, had sold their property at a significant loss, and had endured "noxious odours" for approximately six months. ${ }^{121}$ The RMA does not provide compensation to a plaintiff that is unrelated to avoiding, remedying, or mitigating an adverse effect on the environment. ${ }^{122}$ Compensation is generally limited to instances where the applicant of an enforcement order has undertaken work to prevent environmental damage caused by the neighbours' activities, for example erosion protection works. ${ }^{123}$

Another reason given by the plaintiff's lawyer for pursuing this action was the ability of the plaintiff to "drive the process". ${ }^{124}$ The plaintiff was likely to have felt some exasperation with RMA enforcement procedures. Despite their complaints to the Hawkes Bay Regional Council, the successful prosecution of the defendants under the RMA for the breach of resource consent conditions did not occur until after the plaintiff had relocated their business. ${ }^{125}$ In the meantime, the Council had renewed the plant's discharge to air resource consent. ${ }^{126}$

Davidson provides a good example of the circumstances where the tort of nuisance is likely to be used in New Zealand. Such circumstances involve the failure of local authorities to protect the

120 Mark Hammond, Solicitor, Tompkins Wake, the author (24 June 2003) email.

121 Davidson v Hawkes Bay Protein Limited (2 June 2001) DC Nap 26/98, 4 para 15 Judge Willy.

122 Resource Management Act 1991, s 314(1)(d).

123 Auckland City Council v Sulenta (26 August 1994) Plan Trib AC66/94 Judge Sheppard.

124 Mark Hammond, Solicitor, Tompkins Wake, the author (24 June 2003) email.

125 Davidson, above n 121, 14 para 74.

126 Davidson, above n 121, 15 para 77. 
interests of adjacent property owners and the desire to recover damages for distress and loss caused by the nuisance.

\section{B Implications}

A critical assessment of Davidson reveals that its authority will limit the application of private nuisance, assisting the tort on its path towards obsolescence. Gendall J held that Judge Willy in the District Court had erred in equating "loss of enjoyment or amenity value in land" with personal injury and quashed the award for separate damages to Mr and Mrs Davidson. ${ }^{127}$ In doing so, Gendall J applied the judgment of Lord Hoffman in Hunter. This judgment overruled Bone v Seale, which had previously equated damages for loss of amenity with personal injury. ${ }^{128}$

The award for the loss in property value was also quashed. Gendall $\mathrm{J}$ referred to passages in Lord Hoffman's and Lord Berwick's judgments which offered obiter comment regarding the effect on the capital value of properties arising from a transitory nuisance. ${ }^{129}$ Gendall $\mathrm{J}$ held that in the case of a transitory nuisance, the capital value of a property would seldom be reduced. ${ }^{130}$ Moreover, he found that the diminution of the property's value could not be solely attributed to the existence of the nuisance. ${ }^{131}$

The most significant aspect of Gendall J's judgment is his finding that in a case involving a "nuisance of the kind that concerns interference of enjoyment of property through noise and noxious smells and the like, the primary remedy in most cases is an injunction." 132 While damages were available for the "loss in amenity value of the property", ${ }^{133}$ Gendall $\mathrm{J}$ held that plaintiffs were required to mitigate their loss and that an injunction was a "reasonable and essential step" that they should have taken. ${ }^{134}$ Thus damages were reduced to reflect the plaintiff's failure to seek an injunction. ${ }^{135}$

Regardless of the merits of Gendall J's approach, Davidson has meant that the tort of nuisance has lost any remaining glimmer of attractiveness as a legal tool in personal discomfort cases. Not

127 Davidson, above n 36, 11 para 51.

128 Bone $v$ Seale [1975] 1 WLR 797 (CA) Stephenson LJ cited in Hunter v Canary Wharf Ltd above n 7, 706 (HL) Lord Hoffmann.

129 Hunter v Canary Wharf Ltd, above n 7, 696 Lord Berwick and 706 Lord Hoffman.

130 Davidson, above n 36, 11 para 50.

131 Davidson, above n 36, 10 para 48.

132 Davidson, above n 36, 7 para 32.

133 Davidson, above n 36, 8 para 38.

134 Davidson, above n 36, 11 para 50.

135 Davidson, above n 36, 14 para 58. 
only are damages likely to be meagre if an injunction is not sought, but also seeking an injunction presents a great risk to a potential plaintiff as he or she must give an undertaking for damages to the defendant if the action fails. ${ }^{136}$ This presents a dilemma in circumstances such as in Davidson where the local authority has failed to act within a reasonable period of time to prevent the nuisance. As the lawyer for the plaintiffs explained, in response to the question of why the Davidsons did not seek an injunction: ${ }^{137}$

There was an element of commercial realism applied. Hawkes Bay Protein was a substantial company and had deep pockets. My client did not. The downside of obtaining an injunction, and failing substantively was huge and untenable. HB Protein would have potentially been able to sue for any losses whilst it was closed if we did not win the substantive action.

The application of the tort to nuisances involving non-physical damage has been severely constrained by Davidson. There seems little point in a potential plaintiff incurring the substantial risk associated with a claim for an injunction, when the award of damages is unlikely to be beneficial. Fleming has observed that there is a trend to restrict damages to the impaired value of the land rather than personal impact, as exemplified by Lord Hoffman's judgment in Hunter, which "stands against current practice, besides undercutting valued personality interests." ${ }^{138}$ This development in private nuisance fails to take into account the impact that non-physical harm such as noise interference and noxious odours can have on people's lives.

Thus, the potential plaintiff in a situation involving interference with the use and enjoyment of their property will rely on the RMA to provide relief. Generally, this should not pose a problem. As outlined earlier in this paper, the RMA provides a sound set of enforcement mechanisms to end the nuisance situation. In addition, local authorities, as indicated in the case studies above, are usually responsive to the needs of potential plaintiffs. However, complete reliance on the RMA to resolve personal discomfort claims is not desirable as the following section explains.

\section{AN OPPORTUNITY LOST?}

\section{A Nothing Lost?}

Many people may claim that nothing is lost by the inability to use private nuisance as a legal tool for personal discomfort claims. In fact, it can be argued that this is desirable and that the tort of nuisance is incapable of being a useful legal tool in the protection of the neighbourhood amenity and

136 Mark Hammond, Solicitor, Tompkins Wake, the author (26 August 2003) email; High Court Rules, r 238(3).

137 Hammond, above n 136.

138 Fleming, above n 4, 494. 
the environment generally. The statutory environmental management framework is clearly better suited to the management of environmental issues. As Lord Hoffman acknowledged in Hunter:139

[T] he planning system is, I think, a far more appropriate form of control, from the point of view of both the developer and the public, than enlarging the right to bring actions for nuisance at common law. It enables the issues to be debated before an expert forum.

Moreover, as a practising RMA lawyer has commented, enforcement procedures under the RMA "will often be a cheaper and more expeditious" way of obtaining redress when compared to bringing a common law action. ${ }^{140}$

\section{B Costs of Disuse}

These arguments fail to recognise that many personal discomfort claims will fall outside the planning control processes and the RMA will fail to provide an adequate remedy. For instance, as in the case of Greenwood, a planning officer may not realise that a proposed building's glass verandah may generate significant glare and that it may seriously affect the comfort of the neighbouring landowners. ${ }^{141}$ Moreover, complete reliance on the RMA is only satisfactory when a local authority is able and willing to respond to end a nuisance situation. This is not always the case, as demonstrated by Davidson, where the local authority decided to extend the term of the resource consent despite the complaints it had received about the odour generated by the factory. ${ }^{142}$

A potential plaintiff faced with a reluctant local authority is able to pursue the option of applying for an enforcement order from the Environment Court. ${ }^{143}$ However, this option will take time to be heard before the Court and will not provide any compensation. ${ }^{144}$ An interim enforcement order may achieve a quick end to a nuisance situation but the applicant will often need to make an undertaking regarding damages in order to compensate the defendant for any economic dislocation suffered. ${ }^{145}$ Thus a potential plaintiff may experience similar drawbacks under the RMA as he or she would under a civil claim but without the prospect of receiving damages. Unless a potential plaintiff is willing to take the risk of a private nuisance claim or an enforcement order

139 Hunter v Canary Wharf Ltd, above n 7, 710 Lord Hoffman.

140 Trevor Daya-Winterbottom "Common Law Remedies and Environmental Liability" (1999) 7(2) Resource Management Bulletin 24, 29.

141 Bank of New Zealand, above n 12.

142 Davidson, above n 121, para 77 Judge Willy.

143 Resource Management Act, s 316.

144 See Part III C Substitutes for Private Nuisance Remedies.

145 Resource Management Act, s 320(2)(b). 
under the RMA, they may be left in a situation where there may be little they can do apart from leave.

One of the main costs of the demise of private nuisance relates to the lack of compensation for personal discomfort claims. A landowner experiencing substantial and unreasonable interference with the use and enjoyment of his or her property as a result of the activities of a neighbour, is unable to obtain any compensation under the RMA. With regard to private nuisance, the precedent established by Gendall $\mathrm{J}$ in Davidson will mean that adequate compensation will only be awarded when a plaintiff has sought an injunction. Furthermore, compensation will not be awarded on the basis of personal injury but rather loss to the amenity value of the land. This development in private nuisance, which appears to have been initiated by Lord Hoffman in Hunter and applied in Davidson by Gendall J, should be subjected to debate. While it is outside the scope of this article to enter into such a debate, a few conclusions may be drawn. This development may have the desirable effect of defining the application of private nuisance and limiting unworthy personal discomfort claims, but it is likely to undermine the application of the tort by limiting the recovery of damages for nonphysical harm.

There are other significant costs associated with the dominance of the RMA and the demise of private nuisance. The obligation of property owners not to cause a nuisance has shifted to local authorities. This has afforded a great deal of protection to potential defendants under the RMA while enlarging the legal liability of local authorities.

From one perspective, the protection afforded to the activities of potential defendants means that society as a whole obtains the benefits of these activities (for example goods and services such as air travel and aggregate for roads). The use of the RMA to regulate land uses, particularly through the concept of reverse sensitivity, may protect some noxious activities from private nuisance claims. This may be a small cost to pay because society has a need for such activities.

There is merit in this argument, but I cannot endorse it entirely. The costs of the tort of private nuisance being rendered redundant are significant. Individual property rights have been curtailed for the benefit of established land uses. Private nuisance has the ability to deliver creative remedies to resolve conflicts between competing land uses, ${ }^{146}$ but it has now been denied this role. Bad land use patterns could be allowed to persist because of the use of the concept of reverse sensitivity in planning.

The Ports of Auckland decision is likely to bring about an increase in judicial review actions against local authorities regarding decisions on resource consent applications and the content of district and regional plans. ${ }^{147}$ As a result, local authorities are likely to become more cautious and

146 Bank of New Zealand, above n 12.

147 Ports of Auckland v Auckland City Council, above n 41. 
perhaps overly regulatory in order to avoid the burden of defending their actions in court. Potential defendants' legal liability will be reduced, but at a cost to the general ratepayer. At the same time, individual property owners are reliant on local authorities for protection against substantial and unreasonable interference with the use and enjoyment of their property.

The present position does not represent a desirable state of affairs. I accept that it is difficult to provide a resource management regime that does not incur some cost to private property owners in respect of the public interest. However, I think that some change is required.

\section{Possible Solutions}

Gearty argues that the tort of private nuisance can be revitalised through internal modifications. ${ }^{148}$ In particular, he suggests the removal of the category of physical harm. Physical harm is more appropriately addressed by the tort of negligence and its removal from the ambit of nuisance would do away with the fault element that has crept into nuisance. Gearty argues that this strategic surrender would open the way for a "new slimmed down and efficient action which could then assume a far greater and more constructive role in the protection of the environment."149

Unfortunately, only a passing reference was made to Gearty's suggestions in Hunter and it is difficult to ascertain whether private nuisance is likely to develop in this direction in the future. ${ }^{150}$ Moreover it is likely to be some time before the House of Lords will address private nuisance again. It is questionable whether the change suggested by Gearty would have the desired effect in New Zealand. It does not address recent developments within the tort that constrain damages nor does it account for the dominant role played by the RMA.

Private nuisance can only take on a robust complementary role to the RMA through changes to the content and application of the RMA. Removal of the application of the concept of reverse sensitivity would go a long way to rectifying the situation. I suggest that the rejection of this concept by the courts would be beneficial. It would avoid the current situation where local authorities protect potentially actionable nuisances.

My suggestion may be wishful thinking because of the general acceptance by the Environment Court of the concept. However, while not specifically addressing reverse sensitivity, Rt Hon Sir Geoffrey Palmer, a key "author" of the RMA also argues for change in the application of the RMA. Palmer is very critical of the application of the RMA by the Environment Court and believes it

148 Gearty, above n 2, 218.

149 Gearty, above n 2, 218.

150 Hunter, above n 7, 692. 
represents the "narrow approach of the past". ${ }^{151}$ Palmer argues that a case needs to be brought to the Court of Appeal to refocus the application of the RMA. 152

The RMA has been subject to a nearly constant process of amendment since its enactment. ${ }^{153}$ Debate still surrounds the content of the RMA. As noted earlier, some commentators on the RMA have argued that the broad definition of "environment" and its inclusion in the purpose of the RMA has resulted in its expansive application. ${ }^{154}$ It has been suggested that if the RMA is amended to exclude social and economic considerations from its purpose, then this may curtail its expansive application. ${ }^{155}$ This could mean that the ambit of regulation would be reduced to apply to activities that generate environmental effects in bio-physical and ecological terms, rather than a consideration of social and economic effects. Through this refocus, the RMA could no longer be legitimately applied to protect an established land use activity that generates adverse environmental effects but at the same time provides social and economic benefits. Such change could open the way for the tort to play a complementary role to the RMA. So far, however, Parliament has resisted any such amendment to the RMA.

Private nuisance may be also revitalised if the courts modify the strict approach of Davidson and Hunter regarding the treatment of damages for personal discomfort private nuisance claims. This could be achieved by reaffirming the decision of Bone $v$ Seale to allow for damages to be awarded to reflect the full effect that the nuisance has had on a plaintiff's use and enjoyment of his or her property. ${ }^{156}$ While future developments in the tort cannot be ruled out, a refocused interpretation of the RMA by the courts, particularly in relation to reverse sensitivity, represents a more likely source of change in the near future.

\section{CONCLUSION}

Baragwananth J's declaration that "[t]he time should be long past when statute and common law were seen as occupying different planes" is apt. ${ }^{157}$ Private nuisance has been rendered ineffective by the RMA. The tort has been denied a role because local authorities make decisions under the RMA about which competing land uses will prevail. The RMA has dominated private nuisance to such an

151 Palmer, above n 79, 170.

152 Palmer, above 79, 170.

153 As of 1 September 2003 there have been seven amendments.

154 Such as removing "environment" from section 2(2)(c) and replacing it with "natural and physical resources"; see generally Bill Armstrong "The Resource Management Act 1991: Has it Delivered on its Objectives?" (2001) 3(9) Resource Management Journal 8, 9.

155 Armstrong, above n 154, 11.

156 Bone v Seale, above n 128.

157 Ports of Auckland v Auckland City Council, above n 41. 
extent that potential nuisance situations are allowed to continue, because the use of neighbouring land has been restricted.

As the case of Davidson has demonstrated, the tool of private nuisance is mostly redundant in relation to personal discomfort claims. Case studies have shown that this does not matter in the majority of nuisance situations because the RMA is able to adequately address the nuisance. However, the costs of the disuse of the tort are significant. There will be situations where potential plaintiffs cannot get relief under the RMA. In addition, compensation for significant discomfort is unlikely to be forthcoming. Another cost is that local authorities will end up bearing the burden of increased legal responsibility in ensuring that a nuisance situation does not arise in the first place.

Whether the tort will ever re-emerge as a useful tool to assist in personal discomfort claims depends on the development of the RMA, such is the extent of the RMA's dominant role in environmental law. A debate regarding the cost of the demise of private nuisance in the face of the regulatory expansiveness of the RMA is desirable. 